\title{
Article \\ Expanded Potential Growing Region and Yield Increase for Agave americana with Future Climate
}

\author{
Sarah C. Davis ${ }^{1,2, * \mathbb{D}}$, John T. Abatzoglou ${ }^{3}(\mathbb{D})$ and David S. LeBauer ${ }^{4}(\mathbb{D}$ \\ 1 Voinovich School of Leadership and Public Service, Ohio University, Athens, OH 45701, USA \\ 2 Department of Environmental and Plant Biology, Ohio University, Athens, OH 45701, USA \\ 3 Management of Complex Systems, University of California, Merced, CA 95343, USA; \\ jabatzoglou@ucmerced.edu \\ 4 College of Agriculture and Life Sciences, University of Arizona, Tucson, AZ 85721, USA; \\ dlebauer@email.arizona.edu \\ * Correspondence: daviss6@ohio.edu; Tel.: +740-597-1459
}

Citation: Davis, S.C.; Abatzoglou, J.T.; LeBauer, D.S. Expanded Potential Growing Region and Yield Increase for Agave americana with Future Climate. Agronomy 2021, 11, 2109. https://doi.org/10.3390/ agronomy11112109

Academic Editors: Domenico Ronga and Sanja Cavar Zeljkovic

Received: 12 July 2021

Accepted: 15 October 2021

Published: 21 October 2021

Publisher's Note: MDPI stays neutral with regard to jurisdictional claims in published maps and institutional affiliations.

Copyright: (c) 2021 by the authors. Licensee MDPI, Basel, Switzerland. This article is an open access article distributed under the terms and conditions of the Creative Commons Attribution (CC BY) license (https:// creativecommons.org/licenses/by/ $4.0 /)$.

\begin{abstract}
Rising crop risk for farmers and greater subsidy costs for governments are both associated with changing climatic conditions, including increased water scarcity. The resilience of Agave spp. in both hot and dry conditions, combined with their wide range of uses, position these plants as novel high-yielding crops suitable for both (i) a warming climate and (ii) agricultural regions with finite water resources. A simple model of the physiological response of Agave americana to variations in solar radiation, temperature, and precipitation was used to predict $A$. americana yields globally at a $4 \mathrm{~km}$ spatial resolution for both contemporary climate and high-end warming scenarios. The potential growing region for $A$. americana expanded by 3-5\% (up to 3 million ha) and potential biomass production increased by $4-5 \%$ (up to $4 \mathrm{Gt}$ of additional biomass) with climate warming scenarios. There were some declines in biomass with the climate warming projected in smaller dispersed locations of tropical South America, Africa, and Australia. The amount of water required for optimal A. americana yield is less than half of the current water required for other crops grown in semi-arid agricultural regions of the southwestern US, and a similar low water demand can be expected in other semi-arid regions of the world. Rock mulching can further reduce the need for irrigation and increase suitable cropland area for $A$. americana by $26-30 \%$. We show that $>10 \mathrm{Mg} \mathrm{ha}^{-1} \mathrm{y}^{-1}$ of $A$. americana biomass could be produced on 27 million ha of cropland without requiring irrigation. Our results suggest that cultivation of $A$. americana can support resilient agriculture in a future with rising temperatures and water scarcity.
\end{abstract}

Keywords: water use efficiency; agriculture; resilience; crop production; CAM; arid; semi-arid; fiber; biofuel

\section{Introduction}

Agave americana L., a novel crop species with very high water use efficiency (WUE), can produce dry biomass yields of $9.3 \mathrm{Mg} \mathrm{ha}^{-1} \mathrm{y}^{-1}$ in semi-arid conditions with less than $600 \mathrm{~mm}$ of annual water inputs [1]. With two to four times the WUE of $\mathrm{C}_{4}$ plants [2], crassulacean acid metabolism (CAM) allows these plants to hydraulically isolate (by roots shrinking away from soil contact and stomata closing) during prolonged periods of drought and to photosynthesize at high rates even during periods of extreme heat $[3,4]$. Stomata open during the night when temperatures are cooler and humidity is higher, which prevents the water loss that would otherwise occur during hot days. This physiological adaptation may serve as an increasingly beneficial trait as temperatures increase and droughts intensify with climate change. Despite the high potential for CAM crops to impart resilience in agroecosystems [5], there is a gap in the current understanding about potential growing locations for novel CAM crops like A. americana in dry conditions. 
Agave species have been grown and harvested throughout arid, semi-arid, humid subtropical, and tropical regions of the world for food, beverages, fiber, and supplemental animal fodder [5]. Over the last decade, some Agave species have been identified for their potential to serve growing bioenergy demands $[1,4,6-10]$. In addition to droughtand heat-tolerance, CAM is also associated with succulent plants that often have high concentrations of soluble sugars that are easily converted to fuels like bioethanol [4]. While some Agave spp. are already commercially cultivated, A. americana has cold tolerance that makes it particularly well-suited to conditions at more temperate latitudes [1,5].

Yields from some commodity crops, such as maize that is currently cultivated in both temperate and semi-arid regions, are projected to decline with moderate levels of climate change [11,12]. More frequent drought events in some regions and more frequent flooding in others have led to an increased burden of risk for farmers and higher subsidization costs for governments [13]. Future warming will lead to reduced water availability from snowmelt in semi-arid regions where water is already scarce [14]. CAM plants like Agave can provide a more resilient cropping system that may offset the risk of other commodity crops as climate extremes intensify in the future [5]. While some commercial Agave crops require irrigation depending on the growing location, there are examples in west central Mexico where A. mapisaga, A. salmiana, and A. tequilana all produced high yields (up to $25-26 \mathrm{Mg} \mathrm{ha}^{-1} \mathrm{y}^{-1}$ ) with no irrigation [15]. In a recent field trial in the southwestern US, A. americana was cultivated with as little as $300 \mathrm{~mm}$ of annual water inputs [1].

Although A. americana is a novel crop, other Agave spp. are produced commercially in Central and South America, Africa, and Asia [4-6] and experimental crops are planted in Australia [7,16]. There has been one experimental field trial of A. americana in the US [1]. Otherwise, there is no recent history of Agave crop production in the US other than in ornamental landscaping, but some recent archeological studies reveal that pre-Colombian populations in the southwestern US cultivated large plantations of Agave [17-19].

Archeological evidence indicates that an Agave species was cultivated in the southwestern US with both channeled irrigation and rock mulching [17]. Rock mulching is a practice that maintains greater amounts of plant available water by placing a layer of rocks on the soil surface to reduce radiation at the soil surface, thereby decreasing evaporative losses. Evaporative losses from soil are greatest in arid environments, and crops in these locations depend heavily on irrigation. Rock mulching as a soil management strategy has been demonstrated to reduce evaporative losses in arid systems by up to $85 \%$ [20], and could potentially negate the need for irrigation of A. americana in arid environments.

This study uses an empirical model to predict Agave growth in current and future climate conditions. Variable cultivation scenarios were simulated to determine (1) the potential changes in biomass yields with future climate condition, (2) the potential changes in growing region for A. americana with climate warming, (3) the reduction in water requirements for $A$. americana relative to current crops in the southwestern US, and (4) if the ancient practice of rock mulching can increase yields while reducing the irrigation needed for optimal production. We simulated yields of A. americana globally using the environmental productivity index (EPI) model from [21] and then compared geospatial biomass projections with current climate conditions, future climate conditions with global temperatures $4{ }^{\circ} \mathrm{C}$ above pre-industrial levels, optimal irrigation inputs, and rock mulching.

\section{Materials and Methods}

\subsection{EPI Model}

A simple model of the physiological response of A. americana to variations in solar radiation, temperature, and precipitation was recently developed [21] based on the EPI that was first described as a predictive modeling tool for CAM plants by Park Nobel [22,23]. The model depends on experimentally determined growth responses of a CAM species to light, minimum temperature, and water inputs. The growth responses to each of these environmental factors is fit to a polynomial equation that estimates an index value. The 
product of the three indices is an EPI that can be used to predict biomass growth with variable environmental conditions [21-23].

Potential crop biomass from A. americana was predicted for each grid cell using the EPI model developed by Niechayev et al. [21]. Environmental parameters (light, temperature, and water) were calculated on a monthly time-step over five years (the anticipated harvest cycle for Agave). The light index $(\alpha)$ was calculated as:

$$
\alpha=\left\{\begin{array}{c}
0, \text { for } I \leq 0.6252 \\
-7 \times 10^{-7} I^{2}+0.0016 I-0.001, \text { for } I>0.6252
\end{array}\right.
$$

where $I$ is the average daily photosynthetically active radiation (PAR) for the month in $\mu \mathrm{mol} \mathrm{m} \mathrm{m}^{-2} \mathrm{~s}^{-1}$, and the minimum index limit is 0 . The water index $(\beta)$ was calculated as:

$$
\beta=\left\{\begin{array}{c}
0, \text { for } P \leq 10.219 \\
0.0279 P-0.2851, \text { for } 10.219<P<46.061 \\
1, \text { for } P \geq 46.061
\end{array}\right.
$$

where $P$ is the total monthly input from precipitation in $\mathrm{mm}$, and limits are set for a minimum index of 0 and a maximum index of 1 . The temperature index $(\Gamma)$ was calculated as:

$$
\Gamma=\left\{\begin{array}{c}
0, \text { for } T\langle-3 \text { or }\rangle 36 \\
-2 \times 10^{-7} T^{5}+0.13 \times 10^{-4} T^{4}-1.66 \times 10^{-4} T^{3}-3.878 \times 10^{-3} T^{2}+0.1052 T+0.352, \text { for }-3<T<36
\end{array}\right.
$$

where $T$ is the mean daily minimum nighttime temperature for a given month in ${ }^{\circ} \mathrm{C}$. We define potentially suitable growing regions for $A$. americana based on a cold hardiness threshold of $\leq-10{ }^{\circ} \mathrm{C}$ as described in Section 2.2 below. Temperature maximums are not limiting because $A$. americana has no reduction in carbon assimilation until leaf temperatures reach $50{ }^{\circ} \mathrm{C}$ and the plants acclimate to temperatures up to $65^{\circ} \mathrm{C}$ [24].

The monthly EPI was calculated as the product of the three environmental indices,

$$
E P I_{\text {month }}=\alpha \times \beta \times \Gamma
$$

then the annual EPI, calculated as the sum of the monthly EPI values, was multiplied by five to simulate growth over a five-year period as:

$$
\mathrm{EPI}=5 \times \sum_{0}^{12} E P I_{\text {month }}
$$

The resulting EPI for the crop was then fit to the linear regression model resolved by Niechayev et al. [21] to calculate total crop dry biomass $\left(\mathrm{Mg} \mathrm{ha}^{-1}\right)$ in each grid cell as

$$
\text { Biomass }_{\text {crop }}=1.7607(E P I)-14.774
$$

\subsection{Climate Simulations}

TerraClimate provides monthly climate and hydroclimate summaries for the land surface of Earth on a $4 \mathrm{~km}$ grid during the period from 1958 to the present using data from WorldClim, CRU Ts4.0 and JRA55 [25]. Future climate data from [14] were used to represent high-end warming scenarios where global mean temperatures reach $4{ }^{\circ} \mathrm{C}$ above pre-industrial levels derived from an ensemble of 23 global climate model projections from models participating in the Coupled Model Intercomparison Project Phase 5 (CMIP5) [26]. These data use TerraClimate and a pattern scaling approach from multiple CMIP5 climate models allowing for interoperability with the historical TerraClimate data. The recent climatologies (1981-2010) were used to calculate environmental indices and the EPI for each point on the grid to predict potential yield of A. americana geospatially without irrigation. We similarly use a $30 \mathrm{yr}$ climatology compatible with the contemporary data to calculate future EPI without irrigation. 
In addition, we calculated irrigation requirements to achieve maximum biomass for both contemporary and high-end warming climates. Optimal irrigation inputs were estimated by calculating the difference between the monthly precipitation and $46 \mathrm{~mm}$, the amount of monthly water input required for the water index $\Gamma$ (Equation (2)) to reach a value of 1 . Secondly, we estimate the effect of rock mulching on the water index for regions where mean annual precipitation (MAP) is less than the optimum (i.e., $<46 \mathrm{~mm}$ monthly). The additional moisture available for plant growth was estimated by multiplying the monthly water index by 0.83 based on Diaz et al. [20] to account for the reduction in evaporation, i.e., additional soil water retained for plant uptake, due to rock mulching. A new water index value was calculated as:

$$
\beta_{\text {rock }}=\beta+0.83 \beta
$$

Six different scenarios were simulated to estimate and compare biomass yield of A. americana:

1. Current (1981-2010) climate;

2. Climate with $4{ }^{\circ} \mathrm{C}$ global warming;

3. Current climate with optimal irrigation inputs;

4. Climate with $4{ }^{\circ} \mathrm{C}$ global warming and optimal irrigation inputs;

5. Current climate with rock mulch added (simulated only where rainfed MAP was less than optimum); and

6. Climate with $4{ }^{\circ} \mathrm{C}$ global warming and rock mulch added (simulated only where rainfed MAP was less than optimum).

In all scenarios, potential growing regions for A. americana were constrained to geographical locations where the mean annual absolute minimum temperature $\left(\mathrm{TN}_{\mathrm{n}}\right)$ is above $-10{ }^{\circ} \mathrm{C}$ (Supplemental Figure S1), consistent with cold hardiness previously described for this species [27]. Temperatures below this threshold would damage the plants and prohibit viability of the crop. While some studies have resolved contemporary and future cold hardiness zones [28] at spatial scales relevant for agricultural decision-making over the US, such information across global lands is not widely available. We developed a proxy for the mean $\mathrm{TN}_{n}$ by computing the difference between the $\mathrm{TN}_{\mathrm{n}}$ and the mean daily minimum temperatures of the coldest month of the year during 1981-2010 from the 0.25 degree ERA- 5 reanalysis product. This difference field was then bilinearly interpolated to the mean daily minimum temperature of the coldest month from TerraClimate to derive a global proxy for $\mathrm{TN}_{\mathrm{n}}$ (described in more detail in Supplemental Information, Supplemental Figures S2 and S3).

\subsection{Analysis of Potential Water Requirements in the Southwestern US}

Irrigation requirements for cropland in the southwestern states of Arizona, California, and Nevada were compared to the potential irrigation requirements for A. americana. Average annual precipitation (Historical Climatography Series; National Centers for Environmental Information) and irrigation inputs were divided by the total cropland area in each state [29]. Optimal irrigation requirements for A. americana were based on the model results described above.

\section{Results}

Geospatial projections of A. americana growth across the globe indicated that precipitation imposed the most widespread constraint on productivity in regions that remain above the minimum temperature threshold of $-10^{\circ} \mathrm{C}$ (Supplemental Figure S4). Light limitations overlapped with the regions where absolute minimum temperatures were below $-10^{\circ} \mathrm{C}$, and temperature limitations within the remaining potential growing regions were less severe than water limitations. Thus, biomass production across the remaining potential growing regions was primarily influenced by water availability, with projected biomass ranging from 0 to $16 \mathrm{Mg} \mathrm{ha}^{-1} \mathrm{y}^{-1}$. 
Potential biomass production of A. americana exceeds $3 \mathrm{Mg} \mathrm{ha}^{-1} \mathrm{y}^{-1}$ on 53 million ha of land (Table 1), and the greatest crop yields can be expected in South America, subtropical islands and coastlands surrounding the Gulf of Mexico, and the old-world tropical regions of Africa and Southeast Asia (Figure 1a). With optimal irrigation added, the high-yielding growing regions (with yields $>10 \mathrm{Mg} \mathrm{ha}^{-1} \mathrm{y}^{-1}$ ) increase in area from 27 to 73 million ha (Table 1), and include greater portions of Mexico, the Southern US, Northern Africa, India, China, and Australia (Figure 1b). With rock mulching, more moderate yield increases were projected in arid and semi-arid locations due to a greater retention of soil moisture in these locations (Figure 1c).
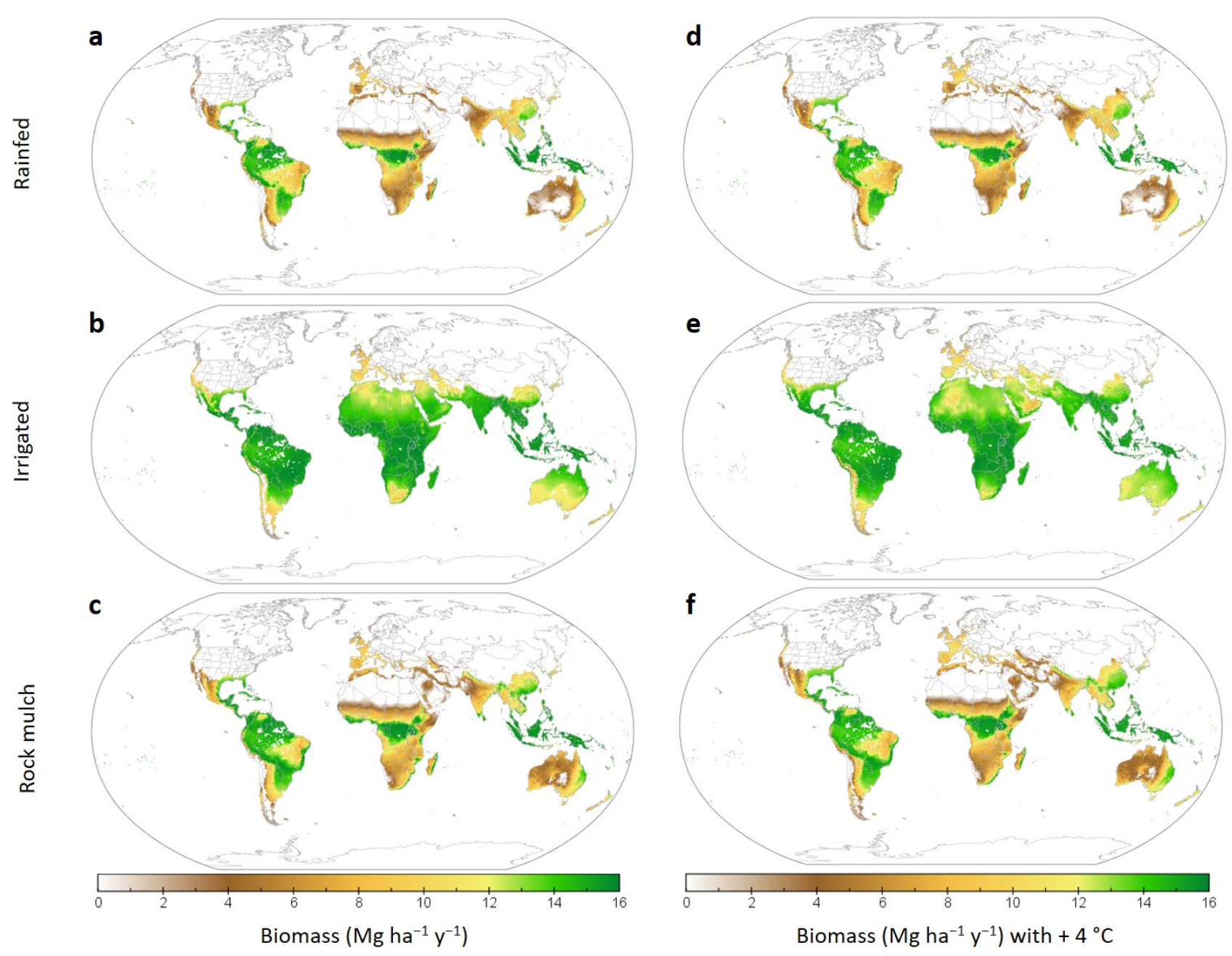

Figure 1. Spatially resolved projections of mean annual biomass production $\left(\mathrm{Mg} \mathrm{ha}^{-1} \mathrm{y}^{-1}\right)$ of $A g a v e$ americana over 5 years, simulated with current climate conditions (left, $\mathbf{a}-\mathbf{c}$ ) and with $+4{ }^{\circ} \mathrm{C}$ warming (right, $\mathbf{d}-\mathbf{f}$ ) and in conditions with native rainfall inputs only $(\mathbf{a}, \mathbf{d})$, with irrigation applied to eliminate water limitation to growth (b,e), and with rock mulching and no irrigation $(\mathbf{c}, \mathbf{f})$. The rock mulch management was only simulated in locations with annual water input less than the optimum in panels $\mathrm{c}$ and $\mathrm{f}$, but all potential land and biomass are shown on the map (inclusive of both lands without rock mulch and lands with the rock mulch that have water inputs lower that optimum) for comparison with the other simulations. Protected areas and urban areas were also removed from the area of simulation. 
Table 1. Summary of potential area $\left(10^{6} \mathrm{ha}\right)$ and potential biomass $\left(10^{9} \mathrm{Mg}\right)$ of Agave americana with different scenarios for climate and management.

Potential Growing Area (Million ha)

Potential Biomass (Gt)

\begin{tabular}{|c|c|c|c|c|c|c|c|}
\hline $\begin{array}{l}\text { Climate } \\
\text { Scenario }\end{array}$ & Management & All Land & $>3 \mathrm{Mg} / \mathrm{ha} / \mathrm{y}$ & $>10 \mathrm{Mg} / \mathrm{ha} / \mathrm{y}$ & All Land & $>3 \mathrm{Mg} / \mathrm{ha} / \mathrm{y}$ & $>10 \mathrm{Mg} / \mathrm{ha} / \mathrm{y}$ \\
\hline 1980-2010 & rainfed & 61 & 53 & 27 & 55 & 54 & 36 \\
\hline$+4{ }^{\circ} \mathrm{C}$ & rainfed & 63 & 55 & 27 & 57 & 55 & 36 \\
\hline 1980-2010 & irrigated & 76 & 77 & 73 & 107 & 107 & 105 \\
\hline$+4{ }^{\circ} \mathrm{C}$ & irrigated & 79 & 80 & 77 & 111 & 111 & 109 \\
\hline 1980-2010 & rock mulch * & 66 & 60 & 34 & 65 & 64 & 46 \\
\hline$+4{ }^{\circ} \mathrm{C}$ & rock mulch * & 69 & 63 & 35 & 68 & 67 & 48 \\
\hline
\end{tabular}

* The rock mulch management was only simulated in locations with annual water input less than the optimum, but numbers in the table are the sum of all potential land and biomass (inclusive of both non-arid lands without rock mulch and arid lands with the rock mulch) for comparison with the other simulations.

The climatically suitable growing region for A. americana is predicted to expand in climate warming scenarios by $2-4$ million ha (Table 1 ; Figure $2 \mathrm{a}, \mathrm{c}$ ). Biomass yields increase with future climate change in most regions (Figure 1, right panels), with a total increase of 1-4 Gt depending on management (Table 1). Some decreases in biomass yields were projected in Brazil, Venezuela, Angola, Morocco, Algeria, Tunisia, and Australia due to increased temperatures combined with precipitation changes (Figure 2a). In the scenarios with irrigation applied, there were declines in projected future yields relative to current conditions in Mauritania, Mali, Algeria, Saudi Arabia, Yemen, and Oman. The largest climate-related increases in biomass production, in scenarios both with and without irrigation, were predicted at the margins of the current growing regions. Northerly expansion of the potential crop range was predicted with a warmer future (Figure 2a,c); this is evident in the United States (Figure 2b,d), Europe, and Asia where growth is currently limited by the extreme minimum temperatures. There were also biomass increases predicted in the Southern hemisphere, specifically in New Zealand and the Andes mountain range in South America (Figure 2a,c).
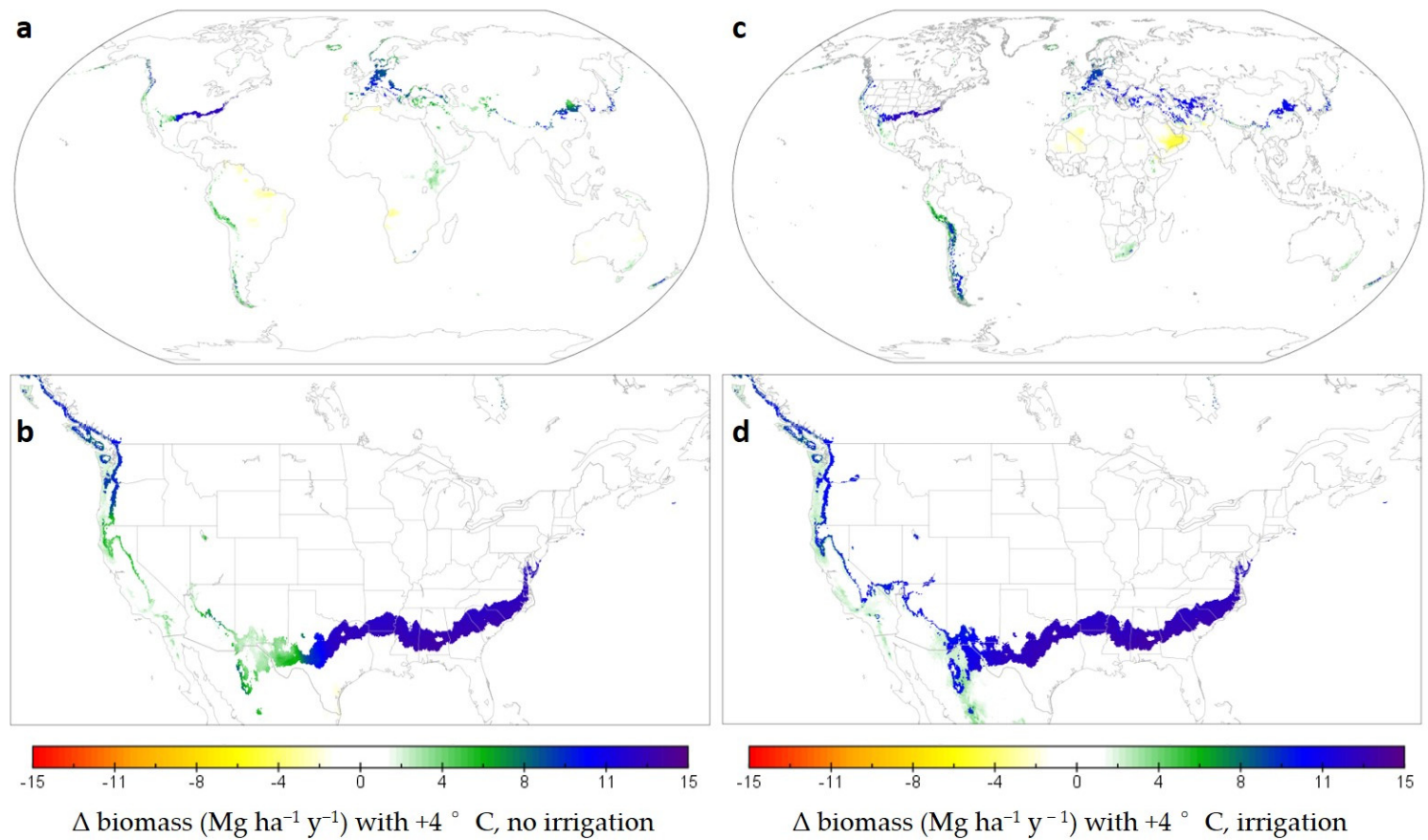

Figure 2. Projected change in potential biomass production $\left(\mathrm{Mg} \mathrm{ha}^{-1} \mathrm{y}^{-1}\right)$ of Agave americana with $+4{ }^{\circ} \mathrm{C}$ warming, globally $(\mathbf{a}, \mathbf{c})$ and in North America $(\mathbf{b}, \mathbf{d})$, and simulated with $(\mathbf{a}, \mathbf{b})$ and without $(\mathbf{c}, \mathbf{d})$ irrigation. 
In North America, A. americana yield differences from east to west are due mostly to water inputs. Biomass projections for $A$. americana indicate that the highest yields can be expected in the southeastern US, Caribbean islands, and the Yucatan peninsula (Figure 3) where annual rainfall amounts are high. With irrigation added (Figure 4), total potential biomass yields from A. americana increased by $93-96 \%$, and biomass yields can reach optimum amounts even in the arid southwestern US and western Mexico. Rock mulching can also support increased biomass yields of $A$. americana in the dry regions of the southwestern US and western Mexico with less irrigation inputs (Figure 4).

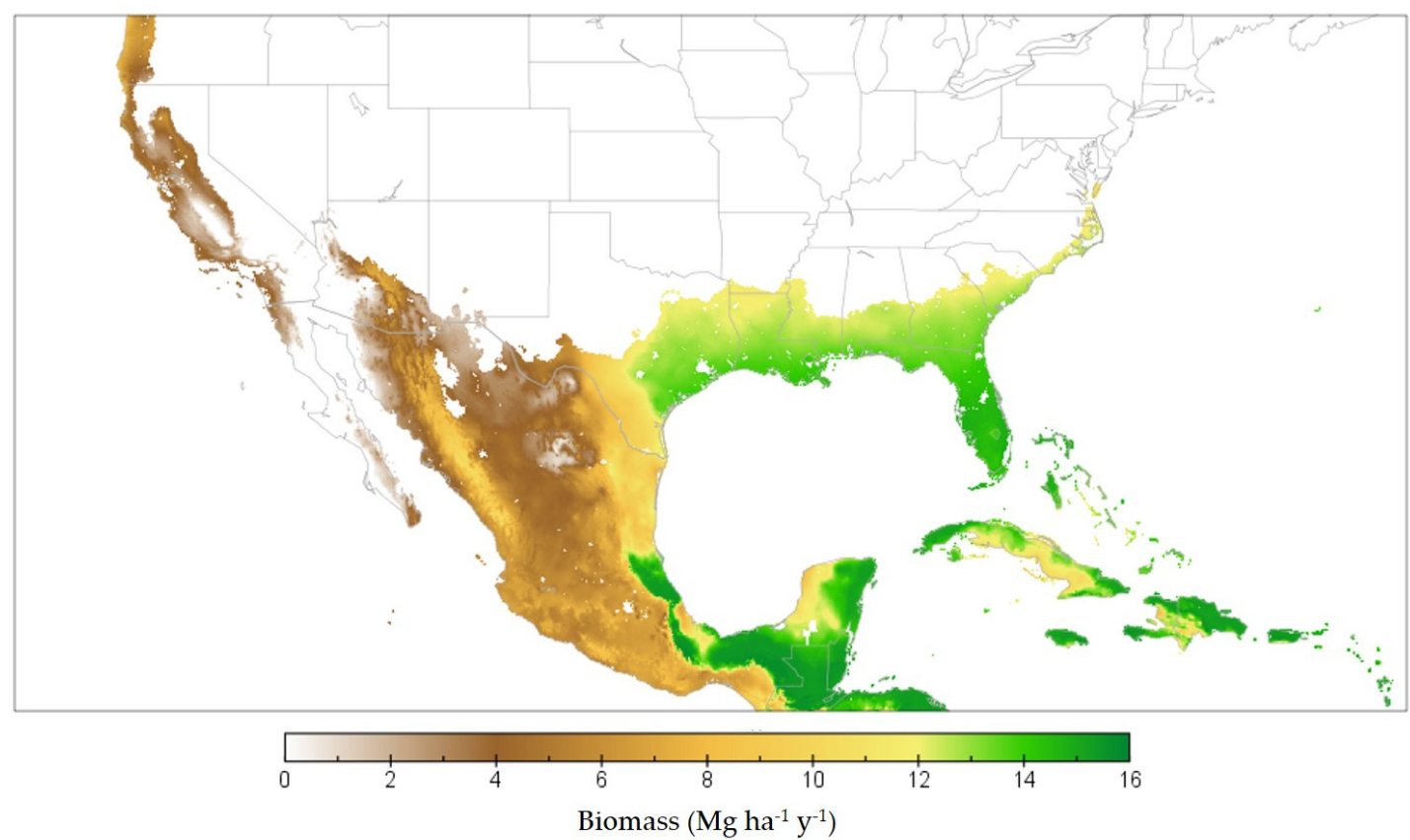

Figure 3. Projections of potential biomass yield $\left(\mathrm{Mg} \mathrm{ha}^{-1} \mathrm{y}^{-1}\right)$ for Agave americana in North America with current climate conditions and no irrigation.

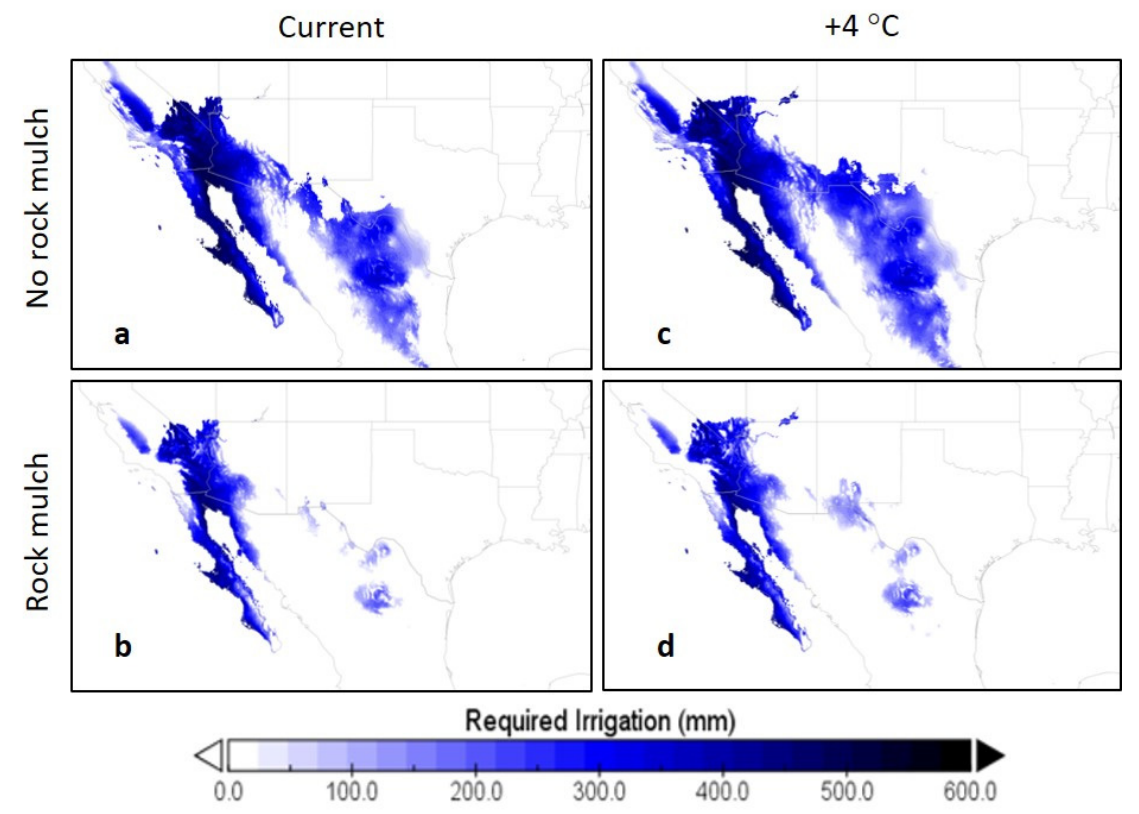

Figure 4. Irrigation required to achieve maximum production of Agave americana in the arid southwestern US and western Mexico with recent climate (a), with $+4{ }^{\circ} \mathrm{C}$ warming (c), with recent climate plus rock mulching $(\mathbf{b})$, and with $+4{ }^{\circ} \mathrm{C}$ warming plus rock mulching $(\mathbf{d})$. 
The optimal irrigation amounts for maximizing biomass of $A$. americana are relatively low compared to the current irrigation amounts that are typical in southwestern states of the US. Arizona, California, and Nevada rank highest among all states in the US for the volume of irrigation applied per unit area of cropland, with mean water inputs equivalent to $1344 \mathrm{~mm} \mathrm{y}^{-1}, 948 \mathrm{~mm} \mathrm{y}^{-1}$, and $845 \mathrm{~mm} \mathrm{y}^{-1}$, respectively [29]. Optimal water inputs (mm) for achieving maximum biomass of $A$. americana (up to $16 \mathrm{Mg} \mathrm{ha}^{-1} \mathrm{y}^{-1}$ ) are $67 \%$, $63 \%$, and $49 \%$ lower than the mean water inputs in Arizona, California, and Nevada, respectively, in 2013 (Figure 5) [29].

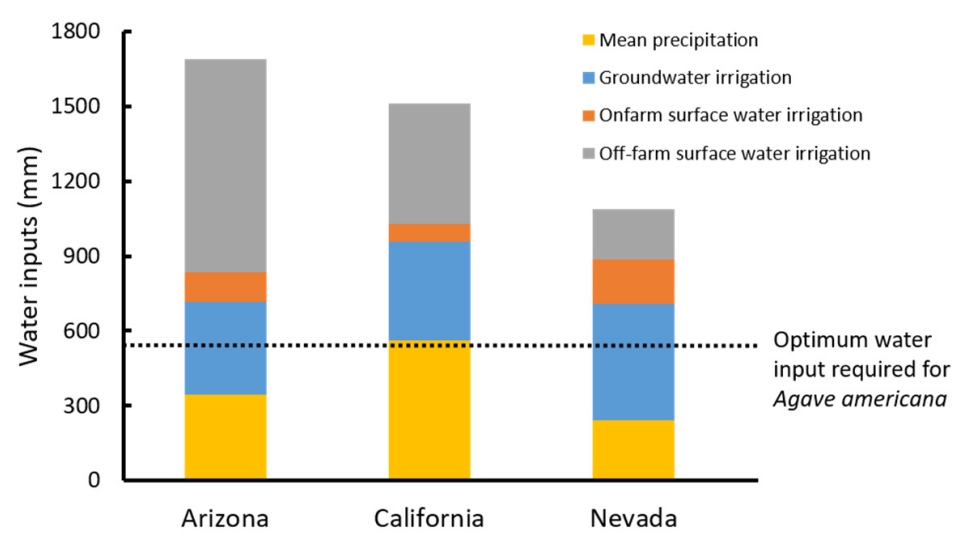

Figure 5. Water inputs from agricultural crops in three southwestern states. Mean precipitation (yellow) reflects the 30-year average [30]. Irrigation from groundwater (blue), onfarm surface water (orange), and off-farm surface water (gray) are distinguished (source: [29]). The dotted line indicates the water requirement required for water to be non-limiting for the growth of Agave americana.

\section{Discussion}

Even though the greatest potential yields were predicted for tropical regions, there are perhaps greater benefits associated with growing $A$. americana in drier regions. Maximum yields will likely not be achieved in arid and semi-arid climates, but $A$. americana can produce greater biomass than many other commodity crops currently grown in these locations and it requires a much lower water input than current crops (e.g., Figure 5). As warming occurs with future climate change, A. americana will have an expanded potential growing range, especially at the northern boundaries of the current range for this species. With a future climate that includes $+4{ }^{\circ} \mathrm{C}$ warming, greater biomass increases would be expected in the northern hemisphere, mostly as a result of increases in minimum temperatures. Only a fraction of the irrigation applied to current crops in arid systems would be required to achieve optimal biomass yields of $A$. americana, making it a more resilient crop alternative for regions like the southwestern US.

Plants that use CAM have underappreciated potential for offsetting risk in agriculture production [5]. Irrigated agricultural lands are estimated to represent half of the economic value of crops which are produced on $28 \%$ of national agricultural land in the US [29]. Here, we determined that optimal water inputs of $A$. americana were lower than current irrigation amounts used for common crops in three states that are drought prone. Areas with increasing incidents of extreme drought are a growing liability [31], and A. americana provides an alternative crop that can persist through drought conditions [1]. For example, in the San Joaquin valley of California, water trading systems are debated and groundwater depletion as a result of irrigation may require cropland to be fallowed [32]. Investment in new drought resilient cropping systems is warranted [13] and might lower the costs of both irrigation and crop insurance risk in the future. If incorporated into a mixed agricultural landscape, a crop like A. americana might reduce the risk of irrigation failure for other crops with higher water demands.

Prior studies indicate that yields will decline for major commodity crops like maize with continued climate change $[11,12]$. While substantial investment in engineering new 
varieties will offset the yield decline with increasingly stressful climatic conditions, there is also tremendous potential, often overlooked, for novel crops like A. americana to become resilient alternatives to supplement current crops. In other previous work, we demonstrated the advantage of $A$. americana for biofuel relative to $\mathrm{C}_{4}$ crops like maize that currently dominates the market [4] and advanced biofuel crops like sorghum and perennial grasses [33]. Agave americana also has potential as a resilient fiber crop in arid to semi-arid regions like Arizona, where greater than a ten-fold improvement in WUE $\left(17.5 \mathrm{~kg} \mathrm{ha}^{-1} \mathrm{~mm}^{-1}\right)$ was observed in a field trial [1] relative to the WUE of cotton $\left(1.4 \mathrm{~kg} \mathrm{ha}^{-1} \mathrm{~mm}^{-1}\right)$. There are also potentially other uses for this crop because closely related species have been used for medicinal purposes and sweeteners (see review in [5]).

There is still much to learn about best management strategies for A. americana and the yield estimates we report here are likely conservative because they do not account for crop improvement that would be accomplished after farmers gain experience with the new crop. Further gains would come if modern breeding and engineering methods were applied to Agave spp. [34]. Recent archeological evidence of large Agave plantations in the southwestern US [18] suggest that there is an historical precedent for this type of crop, even if much of the management knowledge has been lost with time. Ironically, resilient agricultural strategies in the future may benefit from mimicking traditional practices of the past.

\section{Conclusions}

Agave americana is a resilient crop that can offset anticipated agricultural losses from commodity crops due to future climate change. Water inputs required for A. americana are less than half those of typical irrigation in arid and semi-arid agricultural regions. The adoption of the cultivation of Agave americana may complement other solutions to curtail unsustainable water use in working agricultural lands undergoing aridification with climate change. Likewise, this species has potential as a crop in places that are currently deemed unsuitable for agriculture. Potential yields of $A$. americana are projected to increase in most growing regions as climate change progresses.

Supplementary Materials: The following are available online at https:/ /www.mdpi.com/article/ 10.3390/agronomy11112109/s1, Supplemental Information, Figure S1: Absolute minimum air temperature $\left({ }^{\circ} \mathrm{C}\right)$ mapped on $4 \mathrm{~km}$ grid. Contour lines correspond to $10^{\circ} \mathrm{C}$ increments, with $-10{ }^{\circ} \mathrm{C}$ delineating locations where absolute minimum temperatures would kill Agave americana, Figure S2: Annual average difference of the average minimum temperature of the coldest month of the year and absolute annual daily minimum temperatures for the period 1981-2020 calculated from ERA-5, Figure S3: Comparison of 1981-2010 average $\mathrm{T}_{\mathrm{nn}}$ from (a) GHCN stations and (b) TerraClimate. The median absolute error of TerraClimate was $1.0^{\circ} \mathrm{C}$ across the 806 stations examined, Figure S4: Indices resolved on a 0-1 scale and mapped on a $4 \mathrm{~km}$ grid that constrain the growth of Agave americana due to incoming photosynthetically active radiation ( $a$, light index), precipitation $(b$, water index), and temperature (c, temperature index).

Author Contributions: Conceptualization, S.C.D.; methodology, S.C.D., D.S.L., and J.T.A.; software, D.S.L.; validation, S.C.D., D.S.L., and J.T.A.; formal analysis, S.C.D. and D.S.L.; resources, S.C.D. and D.S.L.; data curation, S.C.D. and D.S.L.; writing — original draft preparation, S.C.D.; writingreview and editing, S.C.D., D.S.L., and J.T.A.; visualization, S.C.D. and D.S.L.; project administration, S.C.D.; funding acquisition, S.C.D. All authors have read and agreed to the published version of the manuscript.

Funding: This research received no external funding.

Data Availability Statement: Outputs, including yield predictions and irrigation maps along with analysis code are available on GitHub at https://github.com/az-digitalag/agave-prediction and archived onon the University of Arizona Research Data Repository (doi:10.25422/azu.data.16828279). Climate data used as inputs to this analysis are from TerraClimate (Abatzoglou et al., 2018, accessed on 1 April 2021). Maps of protected lands are from and the public repositories listed below: UNEPWCMC and IUCN (2021); Protected Planet: The World Database on Protected Areas (WDPA) and 
World Database on Other Effective Area-based Conservation Measures (WD-OECM) [Online], 1 April 2021, Cambridge, UK: UNEP-WCMC and IUCN, available at: www.protectedplanet.net; maps of urban areas from Andy South (2017), rnaturalearth: World Map Data from Natural Earth, R package version 0.1.0, https:/ /CRAN.R-project.org/package=rnaturalearth (accessed on 1 April 2021); Kelso, Nathaniel Vaughn, and Tom Patterson, "Introducing natural earth data-naturalearthdata.com." Geographia Technica 5.82-89 (2010): 25.

Acknowledgments: The Faculty Fellowship program at Ohio University supported this study.

Conflicts of Interest: The authors declare no conflict of interest.

\section{References}

1. Davis, S.; Kuzmick, E.R.; Niechayev, N.; Hunsaker, D.J. Productivity and water use efficiency of Agave americana in the first field trial as bioenergy feedstock on arid lands. GCB Bioenergy 2017, 9, 314-325. [CrossRef]

2. Borland, A.M.; Griffiths, H.; Hartwell, J.; Smith, J.A.C. Exploiting the potential of plants with crassulacean acid metabolism for bioenergy production on marginal lands. J. Exp. Bot. 2009, 60, 2879-2896. [CrossRef] [PubMed]

3. Cushman, J.C.; Davis, S.C.; Yang, X.; Borland, A.M. Development and use of bioenergy feedstocks for semi-arid and arid lands. J. Exp. Bot. 2015, 66, 4177-4193. [CrossRef] [PubMed]

4. Davis, S.C.; LeBauer, D.S.; Long, S.P. Light to liquid fuel: Theoretical and realized energy conversion efficiency of plants using Crassulacean Acid Metabolism (CAM) in arid conditions. J. Exp. Bot. 2014, 65, 3471-3478. [CrossRef] [PubMed]

5. Davis, S.C.; Simpson, J.; Gil-Vega, K.D.C.; Niechayev, N.; Van Tongerlo, E.; Castano, N.H.; Dever, L.V.; Búrquez, A. Undervalued potential of crassulacean acid metabolism for current and future agricultural production. J. Exp. Bot. 2019, 70, 6521-6537. [CrossRef] [PubMed]

6. Davis, S.C.; Dohleman, F.G.; Long, S. The global potential for Agave as a biofuel feedstock. GCB Bioenergy 2010, 3, 68-78. [CrossRef]

7. Holtum, J.A.M.; Chambers, D.; Morgan, T.; Tan, D.K.Y. Agave as a biofuel feedstock in Australia. GCB Bioenergy 2010, 3, 58-67. [CrossRef]

8. Lewis, S.M.; Gross, S.; Visel, A.; Kelly, N.M.; Morrow, W. Fuzzy GIS-based multi-criteria evaluation for US Agave production as a bioenergy feedstock. GCB Bioenergy 2014, 7, 84-99. [CrossRef]

9. Owen, N.A.; Griffiths, H. Marginal land bioethanol yield potential of four crassulacean acid metabolism candidates (Agave fourcroydes, Agave salmiana, Agave tequilana and Opuntia ficus-indica) in Australia. GCB Bioenergy 2014, 6, 687-703. [CrossRef]

10. Yan, X.; Tan, D.K.Y.; Inderwildi, O.R.; Smith, J.A.C.; King, D.A. Life cycle energy and greenhouse gas analysis for agave-derived bioethanol. Energy Environ. Sci. 2011, 4, 3110-3121. [CrossRef]

11. Ortiz-Bobea, A.; Ault, T.R.; Carrillo, C.M.; Chambers, R.G.; Lobell, D.B. Anthropogenic climate change has slowed global agricultural productivity growth. Nat. Clim. Chang. 2021, 11, 306-312. [CrossRef]

12. Ruane, A.C.; Antle, J.; Elliott, J.; Folberth, C.; Hoogenboom, G.; Mason-D'Croz, D.; Müller, C.; Porter, C.; Phillips, M.M.; Raymundo, R.M.; et al. Biophysical and economic implications for agriculture of $+1.5^{\circ}$ and $+2.0^{\circ} \mathrm{C}$ global warming using AgMIP Coordinated Global and Regional Assessments. Clim. Res. 2018, 76, 17-39. [CrossRef] [PubMed]

13. Davis, S.C.; Kloepfer, J.E.; Mayer, J.A.; Cushman, J.C. Diversifying Agriculture with Novel Crop Introduction to Abandoned Lands with Suboptimal Conditions. In Climate Change and Crop Production: Foundations for Agroecosystem Resilience; Benkeblia, N., Ed.; CRC Press: Boca Raton, FL, USA, 2018; pp. 163-172.

14. Qin, Y.; Abatzoglou, J.T.; Siebert, S.; Huning, L.S.; AghaKouchak, A.; Mankin, J.S.; Hong, C.; Tong, D.; Davis, S.J.; Mueller, N.D. Agricultural risks from changing snowmelt. Nat. Clim. Chang. 2020, 10, 459-465. [CrossRef]

15. Nobel, P.S. Achievable productivities of certain CAM plants: Basis for high values compared with C 3 and C 4 plants. New Phytol. 1991, 119, 183-205. [CrossRef] [PubMed]

16. Yan, X.; Corbin, K.R.; Burton, R.A.; Tan, D.K. Agave: A promising feedstck for biofuels in the water-energy-food-environment (WEFE) nexus. J. Clean. Prod. 2020, 231, 121283. [CrossRef]

17. Fish, S.K.; Fish, P.R.; Miksicek, C.; Madsen, J. Prehistoric agave cultivation in southern Arizona. Desert Plants 1985, 7, 107-112.

18. Hodgson, W.C.; Salywon, A.M.; Doelle, W.H. Hohokam Lost Crop Found: A New Agave (Agavaceae) Species Only Known from Large-scale pre-Columian Agricultural Fields in Southern Arizona. Syst. Bot. 2018, 43, 734-740. [CrossRef]

19. Ortiz-Cano, H.; Hernandez-Herrera, J.A.; Hansen, N.C.; Petersen, S.L.; Searcy, M.T.; Mata-Gonzalez, R.; Cervantes-Mendívil, T.; Villanueva-Morales, A.; Park, P.M.; Stewart, J.R. Pre-Columbian Rock Mulching as a Strategy for Modern Agave Cultivation in Arid Marginal Lands. Front. Agron. 2020, 2. [CrossRef]

20. Diaz, F.; Jimenez, C.; Tejedor, M. Influence of the thickness and grain size of tephra mulch on soil water evaporation. Agric. Water Manag. 2005, 74, 47-55. [CrossRef]

21. Niechayev, N.A.; Jones, A.M.; Rosenthal, D.M.; Davis, S.C. A model of environmental limitations on production of Agave americana L. grown as a biofuel crop in semi-arid regions. J. Exp. Bot. 2019, 70, 6549-6559. [CrossRef] [PubMed]

22. Nobel, P. Environmental Biology of Agaves and Cacti; Cambridge University Press: Cambridge, UK, 1988.

23. Nobel, P.S. Environmental influences on CO2 uptake by agaves, cam plants with high productivities. Econ. Bot. 1990, 44, 488-502. [CrossRef] 
24. Nobel, P.; Smith, J.A.C. High and low temperature tolerances and their relationships to distribution of agaves. Plant Cell Environ. 1983, 6, 711-719.

25. Abatzoglou, J.T.; Dobrowski, S.; Parks, S.A.; Hegewisch, K.C. TerraClimate, a high-resolution global dataset of monthly climate and climatic water balance from 1958-2015. Sci. Data 2018, 5, 170191. [CrossRef] [PubMed]

26. Taylor, K.; Stouffer, R.; Meehl, G. An overview of CMIP5 and the experimental design. Am. Meteorol. Soc. 2012, 93, 485-498. [CrossRef]

27. Gentry, H.S. Agaves of Continental North America; University of Arizona Press: Tucson, AZ, USA, 1982.

28. Parker, L.; Abatzoglou, J. Projected changes in cold hardiness zones and suitable overwinter ranges of perennial crops over the United States. Environ. Res. Lett. 2016, 11, 034001. [CrossRef]

29. USDA, United State Department of Agriculture. Economic Research Service 2013 Data Summary. 2020. Available online: https:/ / www.ers.usda.gov / data-products/irrigated-agriculture-in-the-united-states/ (accessed on 29 October 2020).

30. National Centers for Environmental Information (Formerly National Climate Data Center). Historical Climatography Series 4-2. 2020. Available online: https:/ / wrcc.dri.edu/Climate/ (accessed on 4 November 2020).

31. USDA, United State Department of Agriculture. Risk Management Agency Rainfall Index. 2021. Available online: https: / / www.rma.usda.gov/en/Policy-and-Procedure/Insurance-Plans/Rainfall-Index (accessed on 20 February 2021).

32. Hanak, E.; Escriva-Bou, A.; Gray, B.; Green, S.; Harter, T.; Jezdimirovic, J.; Lund, J.; Medellin-Azuara, J.; Moyle, P.; Seavy, N. Water and the Future of San Joaquin Valley; Public Policy Institute of California: San Francisco, CA, USA, 2019; p. 100.

33. Jones, A.M.; Zhou, Y.; Held, M.A.; Davis, S.C. Tissue Composition of Agave americana L. Yields Greater Carbohydrates from Enzymatic Hydrolysis Than Advanced Bioenergy Crops. Front. Plant Sci. 2020, 11, 654. [CrossRef]

34. Monja-Mio, K.M.; Herrera-Alamillo, M.A.; Sánchez-Teyer, L.F.; Robert, M.L. Breeding Strategies to Improve Production of Agave (Agave spp.). In Advances in Plant Breeding Strategies: Industrial and Food Crops; Springer: Cham, Switzerland, 2019 ; pp. 319-362. 